\title{
Peerbandingan saturasi oksigen pada orang yang tinggal di pesisir pantai dan yang tinggal di daerah pegunungan
}

\author{
${ }^{1}$ Taufik Kaprawi \\ ${ }^{2}$ Maya Moningka \\ ${ }^{2}$ Jimmy Rumampuk \\ ${ }^{1}$ Kandidat Skripsi Fakultas Kedokteran Universitas Sam Ratulangi Manado \\ ${ }^{2}$ Bagian Fisika Kedokteran Universitas Sam Ratulangi Manado \\ Email: t.kaprawi_11_234@ymail.com
}

\begin{abstract}
Oxygen is a basic requirement for survival. Normal blood oxygen level is a measurement of oxygen saturation in the blood. This study aimed to determine the oxygen saturation value of people who lived in highlands and of people who lived in lowlands. This study eas conducted in two places: Girian village Bitung and Wulurmaatus village South Minahasa in October-December 2014. Sampels were 60 people: 30 people living in the highland and 30 people living in the lowland. Data were analyzed by using SPSS 20 and Mann-Whitney test. The Mann-Whitney test showed that there was a difference in oxygen saturation between the highland people and the lowland people with a p value of $0.0001<\alpha=$ 0.05. The lowland people had higher value of oxygen saturation than the highland people. Conclusion: There was a difference in oxygen saturation value between the highland people and the lowland people.
\end{abstract}

Keywords: oxygen saturation, highlands, lowlands

\begin{abstract}
Abstrak: Oksigen merupakan kebutuhan pokok untuk kelangsungan hidup. Tingkat oksigen darah normal adalah pengukuran saturasi oksigen dalam darah. Penelitian ini bertujuan untuk mengetahui nilai saturasi oksigen pada orang yang tinggal di dataran tinggi dan yang tinggal di dataran rendah. Penelitian dilaksanakan di dua tempat yaitu Kelurahan Girian Bawah Kota Bitung dan Desa Wulurmaatus Kabupaten Minahasa Selatan pada bulan Oktober-Desember 2014. Sampel penelitian berjumlah 60 orang yaitu 30 orang yang tinggal di dataran tinggi dan 30 orang yang tinggal di dataran rendah. Data dianalisis menggunakan SPSS 20 dan uji MannWhitney. Hasil uji Mann-Whitney menunjukkan bahwa terdapat perbedaan saturasi oksigen antara orang yang bertempat tinggal di dataran tinggi dan orang yang bertempat tinggal di dataran rendah dengan nilai $p=0.0001<\alpha=0,05$. Yang tinggal di dataran rendah lebih tinggi nilai saturasi oksigennya daripada dataran tinggi. Simpulan: Terdapat perbedaan nilai saturasi oksigen pada orang yang tinggal di dataran tinggi dan yang tinggal di dataran rendah.
\end{abstract}

Kata kunci: saturasi oksigen, dataran tinggi, dataran rendah

Oksigen merupakan kebutuhan pokok untuk kelangsungan hidup. ${ }^{1,2}$ Tingkat oksigen darah normal adalah pengukuran saturasi oksigen dalam darah. Sel darah merah mengandung molekul yang dikenal sebagai hemoglobin yang mengikat oksigen atmosfer, dan membawanya ke berbagai bagian tubuh. ${ }^{3}$ Bila ada jenis variasi dalam kadar oksigen dalam darah, dapat menyebabkan komplikasi kesehatan. ${ }^{2}$ Oksigen berdifusi dari bagian konduksi paru ke bagian respirasi paru sampai alveoli, membran basalis dan endotel kapiler. Dalam darah sebagian besar $0_{2}$ bergabung dengan Hemoglobin (97\%) dan sisanya larut dalam plasma (3\%). Dewasa 
muda pria mengandung kira-kira 280 juta molekul $\mathrm{Hb}$. Satu molekul $\mathrm{Hb}$ sanggup mengikat molekul $\mathrm{O}_{2}$ membentuk $\mathrm{HbO}_{2}$ oksi hemoglobin. ${ }^{2,3}$

Tingkat oksigen dalam tubuh dapat diukur dengan bantuan berbagai metode. Cara yang paling umum untuk menentukan apakah tingkat kejenuhan oksigen yang sehat, adalah dengan bantuan tes darah digunakan untuk memeriksa gas darah arteri. Cara lain yang mudah untuk memeriksa tingkat oksigen dalam darah adalah dengan menggunakan oksimeter., ${ }^{2,4}$

Oksimetri adalah sebuah perangkat kecil yang digunakan untuk mengukur kadar oksigen dalam darah. Ketepatan dan keakrutan pengukuran didasarkan pada berbagai faktor seperti kadar hemoglobin, persentase menghirup oksigen, suhu, aliran darah arteri ke jaringan pembuluh darah dalam tubuh, aliran balik vena darah dan oksigenasi tersebut. ${ }^{2}$ Oximetri sebagai pengukur kadar oksigen, tidak dapat digunakan dalam kondisi medis tetentu seperti ketika seseorang mengalami keracunan karbonmonoksida dan serangan jantung. ${ }^{2,5}$

Sebelumnya, belum pernah dilakukan penelitian di Sulawesi Utara tentang perbandingan saturasi oksigen pada orang yang tinggal di pesisir pantai dan orang yang tinggal di daerah pegunungan,oleh karena itu penulis tertarik untuk meneliti perbedaan saturasi oksigen di dua tempat tersebut.

\section{METODE PENELITIAN}

Penelitian ini merupakan penelitian observasional analitik dengan menggunakan rancangan cross sectional. Dilakukan pada bulan Oktober-Desember 2014 di dua tempat yaitu Kelurahan Girian bawah, Kota Bitung dan Desa Wulurmaatus Kabupaten Minahasa Selatan. Sampel pada penelitian ini berjumlah 60 orang yang terdiri dari 30 orang yang tinggal di dataran tinggi dan 30 orang yang tinggal di dataran rendah yang memenuhi kriteria inklusi.

Pada penelitian ini, variabel bebas adalah orang yang tinggal di pesisir pantai dan pegunungan sedangkan variabel terikat adalah saturasi oksigen. Prosedur penelitian yaitu dilakukan pemilihan sampel yang memenuhi kriteria inklusi dan eksklusi kemudian memberikan penjelasan mengenai cara dan jalannya penelitian. Responden kemudian menandatangani formulir persetujuan informed consent. Alat dan bahan yang digunakan untuk pemeriksaan antara lain alat oksimetri, laptop dan alat tulis menulis. Hasil penelitian dapat dianalisa dengan menggunakan uji Mann-Whitney.

\section{HASIL PENELITIAN}

Tabel 1. Distribusi Usia Responden Penelitian

\begin{tabular}{ccc}
\hline Usia (Tahun) & $\mathrm{n}$ & $\%$ \\
\hline $20-25$ & 33 & 55 \\
$26-30$ & 27 & 45 \\
Total & 60 & 100 \\
\hline
\end{tabular}

Tabel 2. Distribusi Jenis Pekerjaan Responden Penelitian

\begin{tabular}{ccc}
\hline Jenis Pekerjaan & $\mathrm{n}$ & $\%$ \\
\hline Petani & 28 & 46,7 \\
Mahasiswa & 1 & 1,7 \\
Guru & 1 & 1,7 \\
Swasta & 30 & 50,0 \\
Total & 60 & 100 \\
\hline
\end{tabular}

Tabel 3. Nilai saturasi oksigen responden penelitian

\begin{tabular}{ccc}
\hline Saturasi Oksigen & $\begin{array}{c}\text { Dataran } \\
\text { Tinggi }\end{array}$ & $\begin{array}{c}\text { Dataran } \\
\text { Rendah }\end{array}$ \\
\hline Minimum & 70 & 98 \\
Maximum & 98 & 99 \\
Mean & 93,97 & 98,67 \\
Std. deviasi & 6,2 & 0,5 \\
\hline
\end{tabular}

Tabel 4. Analisa hubungan tempat tinggal dan saturasi oksigen

\begin{tabular}{cc}
\hline Saturasi Oksigen & $\mathrm{P}$ \\
\hline $\begin{array}{c}\text { Dataran tinggi } \\
\text { Dataran rendah }\end{array}$ & 0,0001 \\
\hline
\end{tabular}

\section{BAHASAN}

Berdasarkan hasil penelitian, Pada analisa univariat didapatkan hasil bahwa 
responden penelitian terbagi menjadi 2 kelompok usia yaitu usia 20-25 tahun dan usia 26-30 tahun. Usia terbanyak terdapat pada kelompok usia 20-25 tahun dengan jumlah 33 orang (55\%), sedangkan kelompok usia 26-30 tahun hanya berjumlah 27 orang (45\%). Untuk Variabel pekerjaan, Responden terbanyak yaitu swasta dengan jumlah 30 orang (50\%) sedangkan Responden dengan jumlah terendah jika dilihat dari jenis pekerjaannya yaitu mahasiswa dan guru dengan jumlah masing-masing hanya 1 orang $(1,7 \%)$.

Pada pemeriksaan saturasi oksigen yang dilakukan pada orang yang tinggal di dataran tinggi dan orang yang tinggal di dataran rendah, terlihat bahwa bahwa nilai saturasi oksigen minimum di dataran tinggi 70\% dan maksimum 98\% sedangkan nilai minimum di dataran rendah $98 \%$ dan nilai maksimum 99\%. Terdapat perbedaan ratarata saturasi oksigen antara responden yang bertempat tinggal di dataran tinggi (93,97\%) dan bertempat tinggal di dataran rendah (98,67\%).

Berdasarkan analisis bivariat, didapatkan adanya perbedaan rerata saturasi oksigen antara responden yang bertempat tinggal di dataran tinggi dan responden yang bertempat tinggal di dataran rendah. Rerata saturasi oksigen responden yang bertempat tinggal di dataran tinggi adalah 93,97 $\pm 6,2 \%$ sedangkan rerata saturasi oksigen yang bertempat tinggal di dataran rendah adalah $98,67 \pm 0,5 \%$. Analisis perbedaan rerata saturasi oksigen dengan menggunakan uji Mann-Whitney, didapatkan hasil yang signifikan dengan nilai $\mathrm{p}=0,0001<\alpha=$ 0,05 . Hasil yang sama didapatkan oleh Beall dkk yang meneliti tentang perbedaan bentuk adaptasi biologi pada pendaki Andean, Tibean, and East African. Beall dkk melaporkan bahwa terjadi penurunan saturasi oksigen ketika berada pada daerah ketinggian. ${ }^{5}$

Perbedaan ketinggian suatu tempat mengakibatkan munculnya suatu perbedaan kondisi lingkungan setempat, termasuk tekanan udara. Tekanan udara di dataran rendah lebih tinggi dibandingkan dengan dataran tinggi. Hal ini berhubungan dengan faktor adanya gaya gravitasi bumi yang ditimbulkan. Gravitasi di dataran rendah menjadi lebih tinggi karena kedekatannya dengan pusat bumi, sedangkan semakin tinggi suatu daerah, maka semakin menjauhi pusat bumi sehingga gaya gravitasinya semakin lemah. Lemahnya gravitasi ini memunculkan tekanan udara menjadi semakin lemah pula. Tekanan yang rendah ini mengakibatkan tekanan oksigen pada dataran tinggi menjadi rendah. Tubuh akan mengompensasi penurunan tekanan oksigen dengan cara memproduksi 2,3 Biphosphoglycerate (2,3BPG) yang membantu Hb melepaskan $\mathrm{O}_{2}$ dengan cara menurunkan afinitas $\mathrm{Hb}$ terhadap $\mathrm{O}_{2}$ sehingga $\mathrm{O}_{2}$ yang terlepas akan berpindah ke sel dan masuk ke jaringan tubuh untuk menghindari keadaan hipoksia (Bohr effect). Akibatnya, saturasi oksigen seseorang akan lebih rendah dari mereka yang berada di tempat yang lebih rendah. ${ }^{5}$

\section{SIMPULAN}

1. Terdapat perbedaan saturasi oksigen antara orang yang bertempat tinggal di dataran rendah dan yang tinggal di dataran tinggi dimana yang bertempat tinggal di dataran rendah mempunyai nilai saturasi oksigen lebih tinggi.

2. Letak ketinggian suatu daerah mempunyai hubungan yang signifikan dengan saturasi oksigen.

\section{SARAN}

1. Diperlukan penelitian lebih lanjut pada penelitian ini dengan menggunakan variabel yang lain seperti frekuensi pernapasan dan denyut nadi.

2. Melakukan perbandingan antara nilai saturasi oksigen pada laki- laki dan perempuan untuk mengetahui apakah terdapat perbedaan atau tidak di kedua daerah tersebut yaitu di daerah pesisir dan daerah pegunungan.

\section{DAFTAR PUSTAKA}

1. Oksigen. 20114 april [diakses 23 september 2014] available from : 
Kaprawi, Moningka, Rumampuk: Perbandingan saturasi oksigen...

www.researchgate.net/4232417/Oksi gen/

2. Wedaran. Mengukur kadar oksigen. 2012 September 8 [ diakses 23 september 2014- Available from :http://www.wedaran.com//mengukur -kadar-oksigen/

3. Biologi sel. Kadar oksigen dalam darah, 2013 Juni 14 [diakses 23 september 2014]. Available from :www.biologi- sel.com/kadar-oksigen-dalamdarah.html

4. Klik paru. Terapi oksigen 20117 januari 2011 [diakses 23 september 2014] Available from http://www.klikparu.com/terapioksigen_4826.html

5. Bauer C, Gros C, Bartels G (eds). Biophysics and physiology of carbon Dioxide. New York: Springer-Verlag, 2012. 